\section{Tropical Journal of Pathology and Microbiology}

2020 Volume 6 Number 3 March

\title{
A comparative study of Pap smear cytology and histopathology of cervix biopsy
}

\author{
Selvanayaki K. ${ }^{\mathbf{1}}$, Archana A. ${ }^{2 *}$
}

DOI: https://doi.org/10.17511/jopm.2020.i03.04

\author{
${ }^{1}$ K.M. Selvanayaki, Associate Professor, Annapoorna Medical College and Hospital, Salem, Tamil Nadu, India. \\ 2* Archana Archana, Associate Professor, Dhanalakshmi Srinivasan Medical College and Hospital, Perambalur, Tamil Nadu, India.
}

Background: Carcinoma cervix is one of the leading causes of death of the female population in developing countries. By virtue of its accessibility, cancer of the cervix can be readily diagnosed even in its preinvasive stage. If treated in the earlier stages the patient can often be cured of the disease. Carcinoma of the cervix is the fourth most frequent cancer in women worldwide and the leading cause of death from cancer in several developing countries including India. The use of cervical smear (Papanicolaou/Pap) as a screening tool has significantly reduced the incidence of cervical cancer. Materials and Methods: The present study was carried out in the department of pathology in a tertiary care hospital over a period of two years. In the two year study period, 2568 pap smears were received. Among these, 194 abnormal smears were identified and they were categorized under The Bethesda System 2014. The histopathological examination of biopsy cervix results of the smears was compared and analyzed. Results: Out of 194 smears studied, reactive changes was 69 $(35.57 \%)$. Atypical squamous cells of undetermined significance were $47(24.23 \%)$. Low grade squamous intraepithelial lesions were $3(1.55 \%)$ and high grade squamous intraepithelial lesions were $29(14.95 \%)$. Atypical endocervical cells were $2(1.03 \%)$. Atypical endocervical cells favor neoplastic was $4(2.06 \%)$ and endocervical adenocarcinoma in situ was $1(0.5 \%)$. Squamous cell carcinoma was $39(20.10 \%)$. The histopathological examination of biopsy cervix results of the above smears was compared and analyzed. Conclusion: This correlative study of Pap smear and histopathological examination of the cervix revealed the overall sensitivity of $97 \%$, the specificity of $74 \%$ and an accuracy of $87 \%$. The false-negative and false-positive cases in this study can be minimized by proper sampling, screening, interpretation and further follow up study of repeat smears.

Keywords: Carcinoma cervix, Cervical smear, Pap smear cytology

Corresponding Author

Archana Archana, Associate Professor, Dhanalakshmi Srinivasan Medical College and Hospital, Perambalur, Tamil Nadu, India.

Email: hselvanayaki@gmail.com

\section{How to Cite this Article}

Selvanayaki KM, Archana A. A comparative study of Pap smear cytology and histopathology of cervix biopsy. Trop J Pathol Microbiol. 2020;6(3):230-237. Available From

https://pathology.medresearch.in/index.php/jopm/ar ticle/view/440
To Browse

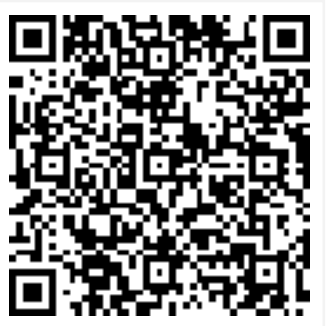

Manuscript Received 13-02-2020

Conflict of Interest No
Review Round 1 22-02-2020

$\mathrm{Nil}$ 27-02-2020

Ethical Approval Yes
Review Round 3

Accepted 04-02-2020

Plagiarism X-checker $13 \%$

Note

(c) 2020 by K.M. Selvanayaki, Archana and Published by Siddharth Health Research and Social Welfare Society. This is an Open Access article licensed under a Creative Commons Attribution 4.0 International License https://creativecommons.org/licenses/by/4.0/ unported [CC BY 4.0]. 


\section{Introduction}

Carcinoma cervix is one of the leading causes of death of the female population in developing countries. According to Global cancer statistics 2018, cervical cancer is the fourth most frequent cancer in women with an estimated 570,000 new cases representing $6.6 \%$ of all female cancers. Approximately $90 \%$ of deaths from cervical cancer occurred in low- and middle-income countries. Cervical cancer ranks fourth for both incidence $(6.6 \%)$ and mortality $(7.5 \%)$ [1].

By virtue of its accessibility, malignancy of the cervix can be readily diagnosed even in its preinvasive stage. If treated in the earlier stages the patient can often be cured of the disease. The introduction of cytological screening by George Papanicolaou in the late 1940 s was a great public health success story in cervical cancer prevention [2].

Although Papanicolaou (Pap) cytology represents the most effective technique to prevent and detect the precancerous conditions of the uterine cervix before they become invasive cancer, its falsenegative yield due to the potential sampling and interpretation errors yield is still a reason of concern. Thus, the final diagnosis should be made on histologic examination to assess the accuracy of the cervical cytology. Cytohistopathological correlation of Pap smear is one of the recommendations of the European guidelines for quality assurance for the development of cytology laboratory performance and, in particular, to reduce false-negative results [3].

The aim of this study was to evaluate women for precancerous and cancerous lesions using the Pap smear test and correlate the cytological findings with histopathological diagnosis.

\section{Materials and Methods}

This study was conducted in a tertiary care hospital, over a period of two years after ethical committee permission was obtained. In the two year study period, 2168 pap smears were received. Among these, 194 abnormal smears were identified and they were categorized under The Bethesda System 2014. The system broadly divides lesions into those negative for intraepithelial neoplasia and epithelial cell abnormalities (ECA) that include squamous and glandular cells.
Smears were stained with Haematoxylin, OG6, and EA36. Tissue material for HPE was fixed in $10 \%$ neutral buffered formalin solution and processed routinely and stained with hematoxylin and eosin (H and $\mathrm{E}$ ).

Study type: Prospective Cross-Sectional study

\section{Inclusion criteria}

01 . Sexually active women were taken for the study

02. Study designs eligible for inclusion in the present study were randomized controlled trials, nonrandomized controlled trials, cross-sectional studies conducted to evaluate the performance of the screening tests for detection of cervical cancer

\section{Exclusion criteria}

01. Pregnant women

02. Studies in which data on sensitivity and specificity of the screening test were not provided were excluded from the study.

Limitations of the study: The sample size is small compared to the population percentage.

\section{Results}

Out of 2168 smears studied, 1974 cases were NILM, Reactive changes were seen in 69 smears (3.21\%). Atypical squamous cells of undetermined significance were (Figure 1) 47 (2.16\%). Low-grade squamous intraepithelial lesions were $3(0.1 \%)$. High-grade squamous intraepithelial lesions (Figure 2) was $29(1.33 \%)$. Squamous cell carcinoma was $39(1.7 \%)$. Atypical endocervical cells were only 2 $(0.1 \%)$. Atypical endocervical cells favor neoplastic was $4(0.18 \%)$ and endocervical adenocarcinoma in situ was $1(0.04 \%)$ [Table 1 ].

The histopathological examination of biopsy cervix results of the above abnormal smears was compared and analyzed. In the histopathological examination results, non-neoplastic lesions were 90 $(46.4 \%)$, premalignant lesions were $31(16 \%)$ and malignant lesions were $73(37.6 \%)$.

Among 90 non-neoplastic lesions, 80 (88.89\%) were chronic cervicitis. Six $(6.67 \%)$ were endocervical polyp, and $4(4.44 \%)$ were squamous metaplasia.

Among 31 premalignant lesions, 12(38.71\%) mild dysplasia, $8(25.81 \%)$ moderate dysplasia (Figure $3)$ and $11(35.48 \%)$ severe dysplasia with carcinoma in situ were detected. 
The total number of malignant lesions was 73. Out of these, well-differentiated squamous cell carcinoma was 19 (26.03\%), moderately differentiated SCC was39 (53.42\%) poorly differentiated SCC was $5(6.85 \%)$ adenosquamous was $4(5.48 \%$ ) and adenocarcinoma (Figure 4) 6 $(8.22 \%)$ [Table 2].

Table-1: Distribution of cases according to their pap smear diagnosis.

\begin{tabular}{|l|l|l|}
\hline \multicolumn{1}{|c|}{ PAP Smear Report } & Number & $\begin{array}{c}\text { Percenta } \\
\text { ge }\end{array}$ \\
\hline Negative for intraepithelial lesion/malignancy & 1974 & 91.05 \\
\hline Reactive cellular changes & 69 & 3.21 \\
\hline $\begin{array}{l}\text { Atypical squamous cells of undetermined significance } \\
\text { (ASCUS) }\end{array}$ & 47 & 2.16 \\
\hline Low-grade squamous intraepithelial lesions (LSIL) & 3 & 0.13 \\
\hline High-grade squamous intraepithelial lesions (HSIL) & 29 & 1.33 \\
\hline Squamous cell carcinoma (SCC) & 39 & 1.79 \\
\hline Atypical endocervical cells (AEC) & 2 & 0.09 \\
\hline Atypical endocervical cells favor neoplastic & 4 & 0.18 \\
\hline Endocervical adeno carcinoma in situ (EAC in situ) & 1 & 0.04 \\
\hline Total & 2168 & $100 \%$ \\
\hline
\end{tabular}

Table-2: Distribution of cases according to their cervical biopsy diagnosis.

\begin{tabular}{|l|l|l|}
\hline \multicolumn{1}{|c|}{ HPE Results } & Number & Percentage \\
\hline Chronic cervicitis & 80 & 41.24 \\
\hline Endocervical polyp & 6 & 3.1 \\
\hline Squamous metaplasia & 4 & 2.06 \\
\hline Mild dysplasia (CIN I) & 12 & 6.19 \\
\hline Moderate dysplasia (CIN II) & 8 & 4.12 \\
\hline Severe dysplasia (CIN III) & 11 & 5.66 \\
\hline Well-differentiated SCC & 19 & 9.8 \\
\hline Moderately differentiated SCC & 39 & 20.10 \\
\hline Poorly differentiated SCC & 5 & 2.58 \\
\hline Adenosquamous carcinoma & 4 & 2.06 \\
\hline Adenocarcinoma & 6 & 3.09 \\
\hline Total & 194 & 100 \\
\hline
\end{tabular}

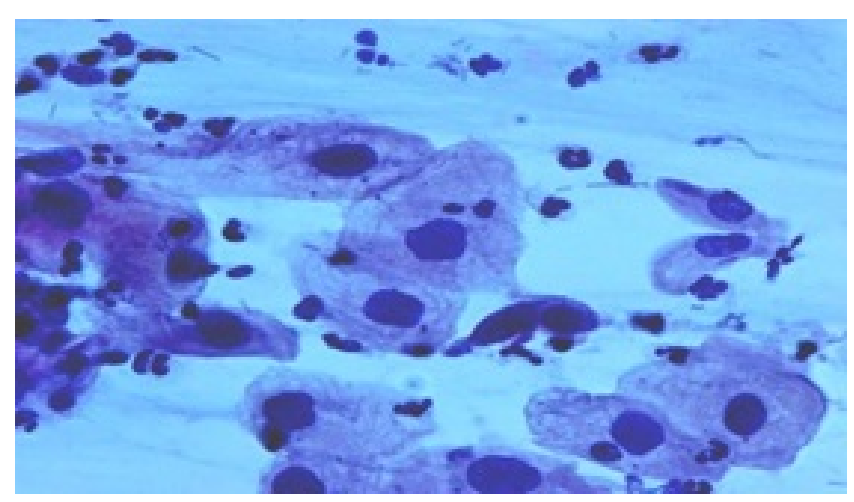

Fig-1: Ascus

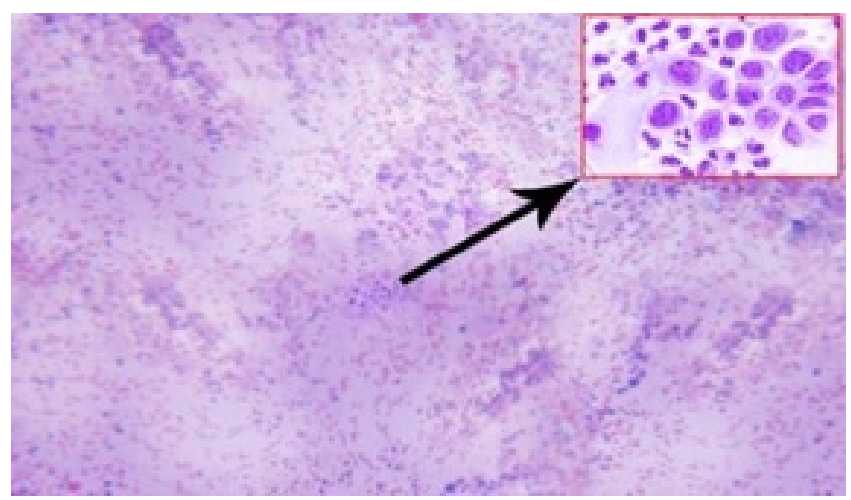

Fig: 2 HSIL

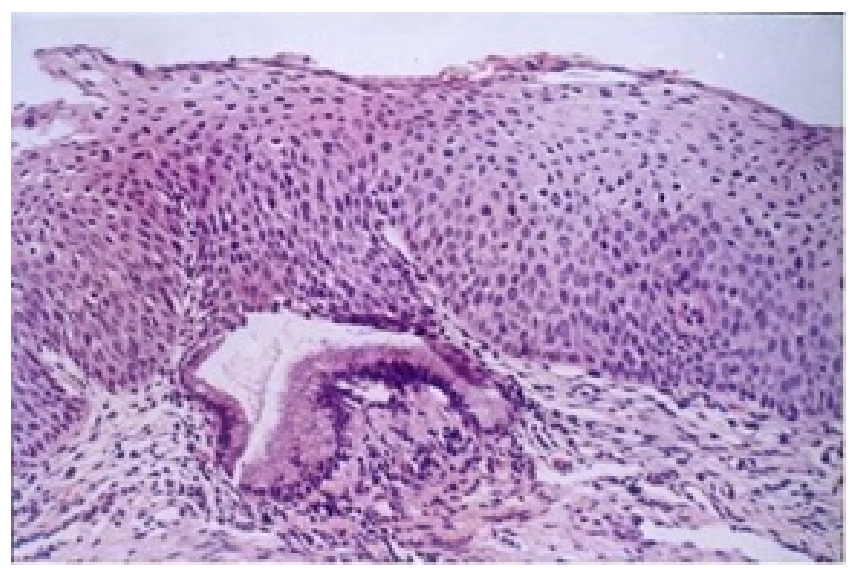

Fig-3: Moderate Dysplasia

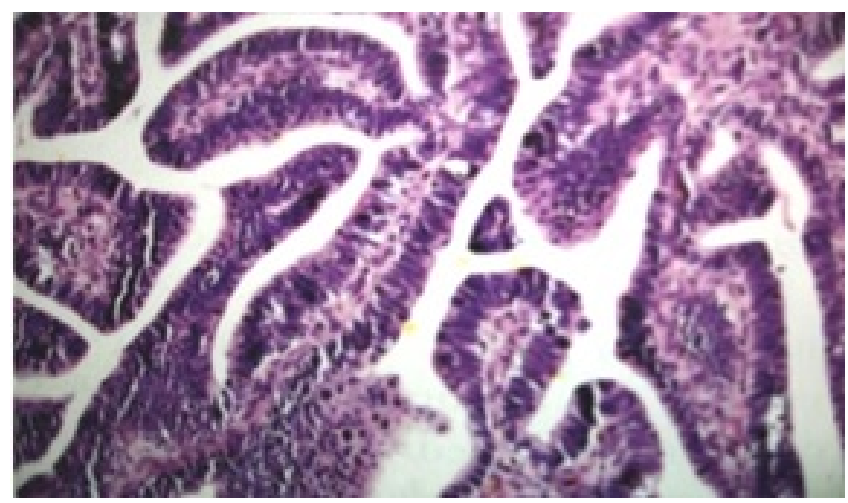

Fig 4: Adenocarcinoma with Glandular Pattern

Cytohistopathological Correlation- Out of 69 reactive cellular changes detected, 64 (92.75\%) cases were reported as chronic cervicitis in histopathological diagnosis, $2(2.9 \%)$ cases were squamous metaplasia, and $1(1.45 \%)$ case was mild dysplasia and one moderate dysplasia (1.45\%) and one endocervical polyp (1.45\%). 47 smears belonged to the ASCUS category. Their histopathological follow up showed $16(34 \%)$ chronic cervicitis, 9 (19.15\%) mild dysplasia, 5 (10.64\%) moderate dysplasia, 2endocervical polyp (4.26\%),7 well-differentiated SCC $(14.9 \%), 6$ moderately differentiated SCC (12.77\%) 
And 2 (4.26\%) squamous metaplasia. 3 smears belonged to the LSIL category, among which 2 $(66.67 \%)$ turned out to be mild dysplasia and one (33.33\%) endocervical polyp.

29 smears belonged to HSIL category which in HPE showed one endocervical polyp $(3.45 \%)$, two $(6.9 \%)$ moderate dysplasia, $11(37.93 \%)$ severe dysplasia with carcinoma in situ, $8(27.59 \%)$ welldifferentiated SCC, $6(20.69 \%)$ moderately differentiated SCC and 1 poorly differentiated SCC (3.45\%).

39 out of 194 smears are the SCC category. In HPE, $4(10.26 \%)$ well-differentiated SCC, $27(69.23 \%)$ moderately differentiated SCC, $4(10.26 \%)$ poorly differentiated SCC and $4(10.26 \%)$ adenosquamous carcinoma. In all cases of histopathologically proved malignancies, smears showed positivity for

\section{Table-3: Cytohistopathological correlation.}

\begin{tabular}{|c|c|c|c|c|c|c|c|c|}
\hline \multirow{2}{*}{$\begin{array}{c}\text { CERVIX BIOPSY } \\
\text { REPORT }\end{array}$} & \multicolumn{8}{|c|}{ Pap smear diagnosis } \\
\hline & Reactive & ASCUS & LSIL & HSIL & SCC & $\begin{array}{l}\text { Atypical } \\
\text { endocervical cells }\end{array}$ & $\begin{array}{l}\text { Atypical endocervical cells } \\
\text { favor neoplastic }\end{array}$ & $\begin{array}{l}\text { Endocervical } \\
\text { adenocarcinoma in situ }\end{array}$ \\
\hline Chronic cervicitis & 64 & 16 & & & & & & \\
\hline Endocervical polyp & 1 & 2 & 1 & 1 & & 1 & & \\
\hline $\begin{array}{l}\text { Squamous } \\
\text { metaplasia }\end{array}$ & 2 & 2 & & & & & & \\
\hline CIN I & 1 & 9 & 2 & & & & & \\
\hline CIN II & 1 & 5 & & 2 & & & & \\
\hline CIN III & & & & 11 & & & & \\
\hline GRADE $1 \mathrm{SCC}$ & & 7 & & 8 & 4 & & & \\
\hline GRADE 2 SCC & & 6 & & 6 & 27 & & & \\
\hline GRADE $3 \mathrm{SCC}$ & & & & 1 & 4 & & & \\
\hline $\begin{array}{l}\text { Adenosquamous } \\
\text { carcinoma }\end{array}$ & & & & & 4 & & & \\
\hline Adenocarcinoma & & & & & & 1 & 4 & 1 \\
\hline
\end{tabular}

Malignancy.

2 smears show atypical endocervical cells in which one turned out to be adenocarcinoma in biopsy and another one showed endocervical polyp. Atypical endocervical cells favor neoplastic is seen in 4 smears and all of them are histopathologically proved to be adenocarcinoma. There is one case of adenocarcinoma in situ in cytology and that is turned out to be adenocarcinoma in biopsy [Table 3].

Coming to the evaluation of the efficacy of the Pap smear test, True positive cases were 103, falsepositive cases were 23, True negative cases were 65 , and false-negative cases were 3 .

The overall sensitivity was $97 \%$, specificity was $74 \%$ accuracy was $87 \%$ and the positive predictive value was $82 \%$.

\section{Discussion}

Cancer is one of the leading causes of death worldwide. Every year about 14 million new cancer cases are detected, and 8 million people die of cancer [4]. However, the worldwide distribution of cancer sites varies in different regions. In developing countries like India cervical cancer is a public health problem due to various factors than in the developed countries so much that one-quarter of the worldwide burden of cervical cancers is in India alone $[4,5]$. It is one of the leading causes of cancer mortality, accounting for $17 \%$ of all cancer deaths in women. Other studies show that cervical cancer will occur in approximately 1 in 53 Indian
Women compared with 1 in 100 women in more developed countries [5].

The cervix is both sentinel for potentially serious genital tract infections and a target for viruses, as well as other carcinogens which may lead to precancerous lesions and invasive carcinoma [6]. The goal of cervical screening is early detection of cervical cancer and precursor lesions. It is stated that the incidence of cervical cancer can be reduced by as much as $80 \%$ if the quality, coverage, and follow-up of screening are high.

Screening for cancer is known to reduce mortality by early detection and treatment $[7,8]$. Unlike other cancer sites, the cervix can be subjected to 
Screening for early diagnosis and treatment. However, despite the availability of various cervical cancer screening methods, as well as the large burden of disease in India, there is no countrywide government-sponsored public health policy on prevention of cervical cancer by either screening or vaccination or both.

This study is aimed at finding out the efficacy of Pap smear in detecting malignant lesions of the cervix in the preinvasive stage. Most cervical cancers start from an area of the dysplastic epithelium

(Transformation zone) which can be detected well by taking a good Pap smear, the best screening program worldwide recommended for sexually active women $[9,10,11]$.

In the present study, the Pap smear examination was compared with histopathological examination the findings of the present study are recapitulated and compared with the results of other studies.

The cases which showed NILM was found to be $91.05 \%$ in the present study. Bal et al [12] reported NILM to be $91 \%$ and another study by Banik et al [13] was $91.8 \%$.the incidence of NILM in the present study was almost the same as the other studies.

Epithelial cell abnormality (ECA): In the present study ECA was present in $8.9 \%$ of the cases. Rubina et al. [14] found the incidence as 6\%, Gazal et al [15] reported $12 \%$. Sherwani et al [16] reported $15 \%$. Bal et al [12] reported $5 \%$, Banik et al [13] found the incidence to be $8.18 \%$, Bukhari et al [17] reported $10.2 \%$.

Table-4: Incidence of NILM in different studies.

\begin{tabular}{|l|l|}
\hline \multicolumn{1}{|c|}{ Present study } & \multicolumn{1}{|c|}{$\mathbf{9 1 . 0 5 \%}$} \\
\hline Bal et al [12] & $91 \%$ \\
\hline Banik et al [13] & $91.8 \%$ \\
\hline Sherwani et al [16] & $85 \%$ \\
\hline
\end{tabular}

Table-5: Incidence of ECA in different studies.

\begin{tabular}{|l|l|}
\hline \multicolumn{1}{|c|}{ Present study } & \multicolumn{1}{c|}{$\mathbf{8 . 9 4 \%}$} \\
\hline Rubina et al [14] & $6 \%$ \\
\hline Ghazal S et al [15] & $12 \%$ \\
\hline Bal et al [12] & $5 \%$ \\
\hline Banik et al [13] & $8.18 \%$ \\
\hline Sherwani et al [16] & $15 \%$ \\
\hline
\end{tabular}

Squamous Cell Abnormality: ASCUS was present in $2.16 \%$ cases, LSIL was present in $0.1 \%$ cases, HSIL in $1.33 \%$ cases and SCC was observed in $1.7 \%$
Cases in the present study. Sherwani et al [16] found $10.6 \%$ cases of LSIL; HSIL was $0.6 \%$ and SCC in $3.7 \%$. Bukhari et al [17] found the incidence of ASCUS as $1 \%$, LSIL as $4 \%$, HSIL as $2.2 \%$ and SCC as $1.4 \%$, Bal et al. reported ASCUS as $0.3 \%$, $\mathrm{ASCH}$ as $0.5 \%$, LSIL as $5.78 \%$, HSIL as $0.7 \%$ and SCC as $1.3 \%$.

The results of the present study have shown a slightly raised incidence of ASCUS as compared to others probably due to the reason that the present study included females coming to gynecological OPD and hence more chances of the positive result.

In the present study, ASCUS and HSIL were found to be more as patients with complaints were included. Differences in other results may be attributed to inter-observer variation. In the present study 2 glandular cell abnormality was detected and 5 adenocarcinomas.

This most widely used screening test as of today is simple and acceptable, but it has been found to have false-negative results ranging from 1.1 to $30 \%$, Chhabra et al $2003(18.7 \%)$, Ozkara et al $2002(5.3 \%)[18,19]$. The false negatives of the present study were 3 .

These results are basically comparable to those reported in other major series using cytohistologic comparison. Variations have been attributed to the difference in cytological expertise, variation in sampling techniques and preparation of the smear. Regarding sampling error and preparation, an artifact like drying artifacts, inadequate fixations, background materials, and thick smears are the most common source of the false negative smears, screening and interpretation mistakes being relatively uncommon $[20,21]$.

Tritz et al found discrepancies between cytologic and histologic diagnoses in 69 out of 615 (11\%) patients with a cytologic diagnosis of neoplastic abnormality, source of error may be inappropriate biopsy or faulty biopsy [23].

The small size of the tumor cells and their scarcity in smears are the major sources of false negativity [24]. Adhesion of cells within the abnormal epithelium is another reason for false negativity. And another important factor is the malignant lesions do not exfoliate at a constant rate.

There are 23 false-positive cases in the present study. It may be due to inadequate biopsy or misinterpretation of the benign process. Anderson 
And Jones documented patients with abnormal smears and initial lack of confirmation by biopsy require long term follow up to discover occult neoplastic lesion [22].

False positivity may be due to removal of the entire lesion by energetic brushing resulting in biopsies with denuded surface or misinterpretation of the cluster of endocervical cells with large nuclei and nucleoli, the cluster of endometrial cells or postmenopausal atrophic cells as abnormal cells.

Various studies mentioned the sensitivity and specificity of cytology for detecting cervical neoplasia that ranged from 50-98\% [25].

There are different methods that were studied to improve cervical screening, but cervical biopsy has been considered as the gold standard for detecting cervical lesions $[18,19]$.

In the present study, sensitivity and specificity of cervical cytology in detecting cervical malignancy were $97 \%$ and $74 \%$ respectively while Dhakal et al [26] and Chhabra et al [18] had a sensitivity of $77.8 \%$ and $81 \%$ respectively and Atla et al [27] had a sensitivity of $94.11 \%$ and specificity of $64.28 \%$.

Table-6: Comparison of the present study with other studies.

\begin{tabular}{|l|l|l|l|}
\hline \multicolumn{1}{|c|}{ Study } & Sensitivity (\%) & Specificity (\%) & Accuracy (\%) \\
\hline Present study & 97.2 & 74.0 & 87.0 \\
\hline Atla et al & 94.1 & 64.2 & 83.3 \\
\hline Joshi et al & 65.3 & 95.8 & 80.0 \\
\hline Dhakal et al & 77.8 & 100 & \\
\hline Patil et al & 77.7 & 84.2 & 82.1 \\
\hline
\end{tabular}

\section{Conclusion}

The study revealed a good correlation between cervical cytology and cervical biopsy. Pap smear is an important screening tool for the detection of precancerous and cancerous lesions of the cervix. It is a less invasive and simple procedure to perform on an OPD basis. Also, it is possible to issue reports within 24 hours of receipt of the specimen.

The present study also concluded that this correlative study of Pap smear and histopathological examination of the cervix revealed the overall sensitivity of $97 \%$, the specificity of $74 \%$ and an accuracy of $87 \%$. The false-negative and falsepositive cases can be minimized by proper sampling, screening, interpretation and further follow up study of repeat smears.

\section{What does the study add to the existing knowledge?}

The success of screening for cervical cancer is based on the collection of adequate materials and the correct interpretation of abnormal cells. Therefore, better awareness, motivation programs along the use of thin-Prep Pap liquid-based cytology technique to reduce inadequate sampling errors is recommended for a virtual $100 \%$ prevention of cervical cancer in the years to come.

\section{Author's contribution}

Dr. K.M. Selvanayaki: Collection of slides, staining, initial reporting and writing of the article

Dr. V. Archana: Review of slides and writing of the article

\section{Reference}

01. Bray F, Ferlay J, Soerjomataram I, Siegel RL, Torre LA, Jemal A. Global cancer statistics 2018GLOBOCAN estimates of incidence and mortality worldwide for 36 cancers in 185 countries. CA Cancer J Clin. 2018;68(6)394-424.

doi: [Article:https://doi.org/10.3322/caac.21492] [Crossref]

02. Drew PA, Wilkinson EJ. Conventional cytology In- Apgar BS, Brotzman GL, Spitzer M, editors, Colposcopy principles and practice, an integrated textbook and Atlas. 2nd Ed, Philadelphia PA- Saunders Elsevier. 2008; p; 5955.

[Crossref]

03. Ferlay J, Soerjomataram I, Ervik M, Forman D, Bray F, Dixit R, et al. GLOBOCAN 2012, Cancer Incidence and Mortality Worldwide in 2012. Lyon, France- International Agency for Research on Cancer. 2012.

[Crossref]

04. Arbyn M, Herbert A, Schenck $U$, Nieminen $P$, Jordan J, McGoogan E, et al. European guidelines for quality assurance in cervical cancer screening- recommendations for collecting samples for conventional and liquid? based cytology. Cytopathol. 2007;18(3)133139.

doi: [Article:https://doi.org/10.1111/j.13652303.2007.00464.x][Crossref] 
05. Institute for Health Metrics and Evaluation. The Challenge Ahead- Progress in Breast and Cervical Cancer. Institute of Health Metrics and Evaluation. 2011.

[Crossref]

06. Ellenson $\mathrm{LH}$, Pirog EC. The female genital tract In- Kumar $\mathrm{V}$, Abbas AK, Fausto N, Aster JC; Robbins and Cotran Pathological basis of disease. 8th Edition Philadelphia- Saunders Elsevier. 2012; 1005-1064.

[Crossref]

07. Morrison AS. Screening in Chronic Disease. 2nd ed; New York- Oxford University Press. 1992; pp-3-42.

[Crossref]

08. Saslow D, Runowicz CD, Solomon D, Moscicki $A B$, Smith RA, Eyre $H J$, et al. American Cancer Society Guidelines for the early detection of Cervical neoplasia and cancer. CA Cancer J Clin. 2002;52(6)342-362.

doi:

[Article:https://doi.org/10.3322/canjclin.52.6.342] [Crossref]

09. Welch HG, Black WC. Evaluating randomized trials of screening. J Gen Intern Med. $1997 ; 12(2) 118-124$.

doi: [Article:https://dx.doi.org/10.1046\%2Fj.15251497.1997.00017.x][Crossref]

10. Wiener HG, Klinkhamer $P$, Schenck $U$, Arbyn $M$, Bulten J, Bergeron C, Herbert A. European guidelines for quality assurance in cervical cancer screening- recommendations for cytology laboratories. Cytopathol. 2007; 18(2)67-78.

doi: [Article:https://doi.org/10.1111/j.13652303.2007.00451.x][Crossref]

11. Sawaya GF, Brown AD, Washington $A E$, Garber AM. Clinical practice- current approaches to cervical cancer screening. N Engl J Med. 2001;344(21)1603-1607.

doi:

[Article:https://doi.org/10.1056/nejm200105243442 107][Crossref]

12. Bal S M, Goyal R. Detection of abnormal cytology in PAP smear. Cyto J. 2012;29(I)45-47. Available from:

[Article:http://www.jcytol.org/text.asp? 2012/29/1/45/93222][Crossref]
13. Sohail R, Nazir R. Evaluaion of pap smear in women attending the gynaecological opd. J Surg Pak. 2008;13(3)121-123.

[Crossref]

14. Gupta S, Sodhani P. Why is high grade squamous intraepithelial neoplasia underdiagnosed on cytology in a quarter of cases? Analysis of smear characteristics in discrepant cases. Indian J Cancer. 2004;41(3)104-108.

[Crossref]

15. Banik U, Bhattacharjee M. Pattem of epithelial cell abnormality in Pap smear- A clinicopathological and demographic correlation. Cyto J. 2011;8(8).

doi: [Article:https://doi.org/10.4103/17426413.80527][Crossref]

16. Sherwani RK, Khan T, Akhtar K, Zeba A, Siddiqui FA, Rahman K, Afsan N. Conventional Pap Smear and Liquid Based Cytology for Cervical Cancer Screening- A Comparative Study. J Cytol. 2007;24(4)167-172.

Available from:

[Article:http://www.jcytol.org/text.asp? 2007/24/4/167/41888][Crossref]

17. Bukhari H, Saba K. Clinicopathological importance of Papanicolaou smears for the diagnosis of premalignant and malignant lesions of the cervix. J Cytol. 2012;29(1)20-25.

Available from:

[Article:http://www.jcytol.org/text.asp? 2012/29/1/20/93213][Crossref]

18. Chhabra Y, Behera BG, Khalkho J, Pati N. Cytomorphological study of PAP smears in precancerous and cancerous lesions. J Cytol. 2003;20(2)64-67.

[Crossref]

19. Ozkara SK, Yıldız K. Retrospective five year analysis of our servicovaginal cytology screening programme under the perspective of Bethesda2001. Turk Bullet Pathol. 2002; 19;119-124. [Crossref]

20. Ghazal S. Pattern and factors affecting Pap smear test in Nablus, a retrospective study. Middle East J Family Med. 2004;4(4).

[Crossref]

21. Yeah GP, Chan KW. The Accuracy of Papanicoaou smear predictions- cytohistological correlation of 283 cases. Hong Kong Med J. 1997;3;373-376.

[Crossref] 
22. Anderson MB, Jones BA. False positive cervico vaginal Cytology. A follow up study - Actacytol. 1997;41(6)1697-1700.

doi: [Article:https://doi.org/10.1159/000333170] [Crossref]

23. Tritz. Discrepancies between cytologic and histologic diagnoses, Koss diagnostic cytology and its histopathologic bases. 5th edition, Lippincot Williams. 2006, Vol - 1; 364-368. [Crossref]

24. Atla BL, Uma $P$, Shamili $M$, Kumar SS. Cytological patterns of cervical pap smears with histopathological correlation. Int J Res Med Sci. 2015;3(8)1911-1916.

doi: [Article:http://dx.doi.org/10.18203/23206012.ijrms20150300][Crossref]
25. Mitch. Medley- Correlation between cytology and biopsy cervix, Koss diagnostic cytology and its histopathologic bases. 5th edition, Lippincot Williams. 2006, Vol - 1; 364-368.

[Crossref]

26. Dhakal R, Makaju R, Sharma S, Bhandari S, Shreshtha S, Bastakoti R. Correlation of Cervical Pap Smear with Biopsy in the Lesion of Cervix. Kathmandu Univ Med J. 2016;55(3)254-257. [Crossref]

27. Boyes DA, Nichols AM, Millner AM, Worth AJ. Recent results from the British Columbia screening program for cervical cancer. Amer J Obstet Gynaecol. 1977;128(6)692-693.

doi: [Article:https://doi.org/10.1016/00029378(77)90223-X][Crossref] 